\title{
Image Processing Artifact
}

National Cancer Institute

\section{Source}

National Cancer Institute. Image Processing Artifact. NCI Thesaurus. Code C87020.

An artifact resulting from data processing steps after capture of an image. 